\title{
Detection of micro-organisms in soil after in situ hybridization with rRNA-targeted, fluorescently labelled oligonucleotides
}

\author{
Dittmar Hahn, ${ }^{1 *}$ Rudolf I. Amann, ${ }^{2}$ Wolfgang Ludwig, ${ }^{2}$ Antoon D. L. Akkermans ${ }^{1}$ and \\ KARL-HEINZ SCHLEIFER ${ }^{2}$ \\ ${ }^{1}$ Agricultural University Wageningen, Department of Microbiology, Hesselink van Suchtelenweg 4, 6703 CT Wageningen, \\ The Netherlands, \\ ${ }^{2}$ Technische Universität München, Lehrstuhl für Mikrobiologie, Arcisstr. 21, 8000 München 2, FRG
}

(Received 6 June 1991; revised 28 October 1991; accepted 29 January 1992)

\begin{abstract}
rRNA sequences were used as targets for synthetic oligonucleotides labelled with the fluorescent dye tetramethylrhodamine isothiocyanate (Tritc) for in situ hybridizations to detect micro-organisms directly in soils that have different contents of soil minerals and organic material. Introduced Pseudomonas aeruginosa cells were directly fixed in soils and applied to slides after separation of large soil minerals only. Remaining soil minerals (clay minerals) and organic material (up to $8 \%$ ) did not significantly interfere with signal expression after hybridization. Background signals were mainly caused by autofluorescence of organic material. Non-specific binding of labelled oligonucleotides to soil particles was not observed. In situ detection of introduced cells of Pseudomonas cepacia in a sandy loam spiked with a mixture of selected soil micro-organisms was possible after hybridization with a specific probe. Analysis of natural bacterial populations in soil, however, was not possible by in situ hybridization without activation of these micro-organisms by adding nutrients. Growing cells, e.g. Streptomyces scabies hyphae growing in amended soil, were easily detected.
\end{abstract}

\section{Introduction}

The analysis of natural microbial communities is limited by reliance on growth-dependent methods for identifying individual species at the phenotypic level. So far, two techniques for specific enumeration of bacteria have been established: selective plating and immunofluorescence (Hill \& Gray, 1967; Bohlool \& Schmidt, 1980; Postma et al., 1988; Thompson et al., 1990). Both techniques depend on the isolation of the target organisms. While selective plating techniques rely on strong phenotypic markers of the target organism, e.g. antibiotic resistance, and their ability to grow on selective media, the immunofluorescence technique needs pure cultures of the target organism in order to raise specific antibodies. However, even though selective isolation procedures do exist for many micro-organisms (Grant \& Holt, 1977; Wellington et al., 1987), most members of natural bacterial communities seem to

* Author for correspondence. Present address: ETH Zürich, Department of Terrestrial Ecology, Grabenstr. 3, CH-8952 Schlieren, Switzerland. Tel. 173360 46; fax 17310783.

Abbreviations: Tritc, tetramethylrhodamine isothiocyanate; DAPI, 4',6-diamidino-2-phenylindole. remain unculturable and their identity unknown (Brock, 1987; Torsvik et al., 1990).

Over the last decade molecular methods based on DNA or rRNA sequence analysis have reached a high level of acceptance in microbial ecology as new techniques for the specific enumeration of bacteria unbiased by the limitations of culturability (Holben $e t$ al., 1988; Fuhrman \& Lee, 1989; Ward, 1989; Sayler et al., 1989). Based on comparative sequence analysis rRNA-directed oligonucleotide probes have been designed and successfully used to detect specific organisms without prior isolation (Stahl et al., 1988; Giovannoni et al., 1990; Hahn et al., 1990a, b), and to monitor population dynamics (Stahl et al., 1988). Recently, the use of the polymerase chain reaction has improved the long-standing problem of limited sensitivity (Steffan \& Atlas, 1988; Bej et al., 1991). Because this technique allows one to retrieve sequence information from nonculturable members of complex communities also (Weller \& Ward, 1989; Ward et al., 1990a, b; Giovannoni et al., 1990; Amann et al., 1991) specific enumeration of these organisms has become possible.

This molecular approach to the analysis of microbial community structure can be combined with conventional 
microscope techniques. rRNA-targeted oligonucleotide probes have been labelled with radioisotopes (Giovannoni et al., 1988) or with fluorescent dyes (DeLong et al., $1989 a, b$; Amann et al., 1990a, b; Amann et al., 1991) and used for detection and identification of individual cells in situ.

The aim of this study was to investigate the applicability of in situ hybridization with fluorescently labelled rRNA-targeted oligonucleotides for the detection of specific target organisms in soil. Similar to the application of fluorescent antibodies for identification of bacteria in soil, protocols for in situ hybridization have to deal with non-specific binding of the probe to soil particles, autofluorescence of soil components, recovery of introduced bacteria and specific detection of a target organism with a large background of non-target organisms (Gray, 1990). These criteria were examined using metabolically active cell material. Further investigations were concerned with the applicability of the optimized procedure to natural bacterial populations.

\section{Methods}

Bacterial strains. Pseudomonas cepacia (DSM 50181) and Pseudomonas aeruginosa (P8, Department of Microbiology, University of Wageningen) were grown in liquid LB medium (Maniatis et al., 1982) at $30^{\circ} \mathrm{C}$. Both organisms were harvested in early stationary phase. Streptomyces scabies (ATCC 23962) was grown on R5 agar plates at $30^{\circ} \mathrm{C}$ (Hopwood et al., 1985). Spore suspensions were obtained also as described by Hopwood et al. (1985).

Oligonucleotide probes. rRNA-targeted oligonucleotide probes designed against 23S rRNA of $P$. cepacia (Höpfl et al., 1989) (PCE 54, 5'CCCATCGCATCTAACAAT), the eubacterial probe Eub338 (Stahl et al., 1989), probe nonEub338, which is complementary to probe Eub338 and the eukaryotic probe Euk516 (Amann et al., 1990b) were synthesized with a primary amino group at the 5'-end (Aminolink 2; Applied Biosystems). The fluorescent dye tetramethylrhodamine isothiocyanate (Tritc; Research Organics, USA) was covalently bound to the amino group, and the dye-oligonucleotide conjugate $(1: 1)$ was purified from unreacted components and stored at $-20^{\circ} \mathrm{C}$ in double distilled water at a concentration of $50 \mathrm{ng} \mathrm{\mu l}^{-1}$ (Amann et al., 1990 b). The DNA-specific dye 4', 6-diamidino-2-phenylindole (DAPI) (Sigma) was stored in a $1 \mathrm{mg} \mathrm{m}^{-1}$ solution at $-20^{\circ} \mathrm{C}$. A dilution of $1 \mu \mathrm{g} \mathrm{ml}^{-1}$ was stored at $4^{\circ} \mathrm{C}$ and used to stain bacterial cells in in situ hybridizations non-specifically (Porter \& Feig, 1980).

Cell fixation. Cells of pure cultures were fixed in $4 \%(w / v)$ paraformaldehyde/PBS (0.13 $\left.\mathrm{M}-\mathrm{NaCl}, 7 \mathrm{mM}-\mathrm{Na}_{2} \mathrm{HPO}_{4}, 3 \mathrm{mM}-\mathrm{NaH}_{2} \mathrm{PO}_{4}\right)$, pH 7.2-7.4 (fixation buffer) for 3-16 h, washed once in PBS and stored in $50 \%(\mathrm{v} / \mathrm{v})$ ethanol/PBS at $-20{ }^{\circ} \mathrm{C}$ until further use (Amann et al., $1990 a$ ).

In situ hybridization. For each sample, either cell suspensions or soil isolations, $1 \mu \mathrm{l}$ and 10 -fold-dilutions were applied to gelatin-coated slides $\left.\left[0.1 \% \text { gelatin, } 0.01 \% \mathrm{KCr}(\mathrm{SO})_{4}\right)_{2}\right]$, and allowed to air-dry. Following dehydration in 50,80 and $100 \%$ ethanol for 3 min, each of the preparations was hybridized in $5 \mu$ l hybridization buffer $(0.9 \mathrm{M}$ $\mathrm{NaCl}, 0 \cdot 1 \% \mathrm{SDS}, 20 \mathrm{~mm}$-Tris/HCl, $\mathrm{pH} 7 \cdot 2)$ and $1 \mu \mathrm{lof}$ probe $(50 \mathrm{ng})$ at $45^{\circ} \mathrm{C}$ for $1 \mathrm{~h}$. After hybridization the slides were washed in hybridization buffer for 20 min at $48^{\circ} \mathrm{C}$, rinsed with distilled water and air-dried. Afterwards $1 \mu \mathrm{l}$ of $1 \mu \mathrm{g}$ DAPI ml-1 was added to each sample, which was then covered with $5 \mu \mathrm{l}$ of hybridization buffer, incubated for $5 \mathrm{~min}$ at room temperature, rinsed with distilled water and air-dried. The preparations were examined with a Zeiss microscope fitted for epifluorescence with a high-pressure mercury bulb and filter sets for $\mathbf{4 0 0}$ and $580 \mathrm{~nm}$ (\# 01 and 15).

Cell extraction from soil. Air-dried, gamma-sterilized sandy loam ( $1 \mathrm{~g})$ in sterile $10 \mathrm{ml}$ Falcon tubes was inoculated with $1.3 \pm 0.2 \times 10^{6}$ cells of $P$. aeruginosa in $100 \mu 1 \mathrm{PBS}$, mixed by vortexing and incubated for $1 \mathrm{~h}$ on ice to allow some binding of the introduced cells to soil particles. Cells were either extracted from the soil prior to cell fixation with $(a)$ $10 \mathrm{ml} 0.1 \%$ sodium pyrophosphate, $\mathrm{pH} 7.2$, or with $($ b) $10 \mathrm{ml} 0.1 \%$ pyrophosphate and a drop of Nonidet P-40 (Sigma), or were directly fixed in the soil sample with either $1 \mathrm{ml}$ or $5 \mathrm{ml}$ of fixation buffer $(4 \%$ paraformaldehyde/PBS, $\mathrm{pH} 7 \cdot 2-7 \cdot 4)$ for 3-16 h. All samples were mixed on a vortex mixer for $10 \mathrm{~s}$ and kept on ice for $2 \mathrm{~min}$ to allow separation of heavy soil particles from the supernatant. The supernatants were removed and the soil pellets re-extracted with either $2 \mathrm{ml}$ PBS or $2 \mathrm{ml}$ of fixation buffer. The combined supernatants of the pyrophosphate extractions were centrifuged at $5000 \mathrm{~g}$ for $15 \mathrm{~min}$, the supernatant discarded and the pellet resuspended in $1 \mathrm{ml}$ of fixation buffer. After fixation for 3-16 h all samples were centrifuged at $8000 \mathrm{~g}$ for $5 \mathrm{~min}$, washed with $1 \mathrm{ml}$ PBS and the pellet resuspended in $1 \mathrm{ml}$ $50 \%$ ethanol/PBS and stored at $-20^{\circ} \mathrm{C}$. One $\mu$ l of each sample as well as 10 -fold-dilutions were used for determination by microscopy of cell recoveries after in situ hybridization.

Soil-dependent detection. Samples (1 g) of seven gamma-irradiated soils containing different amounts of organic substances and of different mineral composition (see Table 1) were inoculated with $1.3 \pm 0.2 \times 10^{6}$ cells of $P$. aeruginosa, mixed by vortexing and incubated for $1 \mathrm{~h}$ on ice to allow some binding of the introduced cells to soil particles. Cells were extracted for epifluorescence microscopy after direct fixation with $5 \mathrm{ml}$ of fixation solution and washed, resuspended and stored as described above. Cell recoveries were determined by microscopy after in situ hybridization and compared with counts of c.f.u. determined after cell extraction with $0 \cdot 1 \%$ sodium pyrophosphate and incubation on LB medium for $24 \mathrm{~h}$ at $30^{\circ} \mathrm{C}$.

Specificity of probes in soil. The influence of soil components on specific detection of bacteria was tested on fixed $P$. cepacia (DSM 50181 ) cells mixed with the extract of $1 \mathrm{~g}$ of sandy loam to which fixed cells of several reference organisms were added in densities of about $10^{8}$ cells of each introduced reference species (see Fig. 2). Prior to their addition, hyphae-forming Gram-positive organisms, e.g. Streptomyces, Frankia and other actinomycetes were sonicated mildly to homogenize cell clumps and were pretreated with $0.1 \%$ lysozyme in PBS for $15 \mathrm{~min}$ at room temperature. Samples of $1 \mu \mathrm{l}$ of the spiked extract were applied to slides and hybridized with probe PCE 54, specific for $P$. cepacia. Reference organisms were visualized by DAPI staining.

Natural populations in soil. Untreated samples of a sandy loam, which had either been kept at $4{ }^{\circ} \mathrm{C}$ or used in a microcosm experiment at $24^{\circ} \mathrm{C}$ for 2 months were fixed, hybridized with the universal probe Eub338 and stained with DAPI as described above. Additionally, soil samples $(1 \mathrm{~g})$ from both treatments were incubated at $30^{\circ} \mathrm{C}$ for $16 \mathrm{~h}$ after addition of $0.2 \mathrm{ml} \mathrm{LB}$ medium prior to fixation and hybridization.

Detection of inactive cells. Pure cultures of $P$. aeruginosa were grown on LB agar plates at $20^{\circ} \mathrm{C}$ and $30^{\circ} \mathrm{C}$, respectively, and samples were fixed after incubation for 1,3 and $30 \mathrm{~d}$.

Freshly grown cells of $P$. aeruginosa in $1 \mathrm{ml}$ LB medium $\left(1.4 \pm 0.2 \times 10^{8}\right.$ cells) were inoculated into $1 \mathrm{~g}$ of air-dried gammairradiated sandy loam in tubes, mixed and incubated on ice for $1 \mathrm{~h}$ to allow some binding to soil particles. The tubes were incubated at $20^{\circ} \mathrm{C}$ and fixed after $0,1,2,4$ and $5 \mathrm{~d}$. After $4 \mathrm{~d}, 1 \mathrm{ml} \mathrm{LB}$ medium was added to the remaining tube which was fixed after incubation for a further 
day. Bacteria were extracted for epifluorescence microscopy using the eubacterial probe Eub338 and DAPI staining as described above. Duplicates of the tubes were used for determination of c.f.u.

Detection of growing organisms. Sterile, amended sandy loam $(1 \%$, $\mathrm{w} / \mathrm{v}$, starch, $1 \%$, w/v, chitin) was inoculated with about $10^{8}$ spores $\mathrm{g}^{-1}$ of Streptomyces scabies (ATCC 23962) and incubated at $22^{\circ} \mathrm{C}$ for $5 \mathrm{~d}$ to allow spore germination and mycelium development (Herron \& Wellington, 1990). Growing mycelium was extracted for epifluorescence microscopy after direct fixation with $5 \mathrm{ml}$ of fixation solution and washed, resuspended and stored as described above. One $\mu \mathrm{l}$ of each sample was applied to the slides and used for in situ hybridization with probe Eub338.

\section{Results}

\section{Extraction procedure}

The technique of in situ hybridization with rRNAtargeted oligonucleotides labelled with a fluorescent dye (Tritc) was applicable in soil samples. Background signals due to autofluorescence of organic material present in soil could be quite intense. Non-specific binding of oligonucleotides (nonEub338, Euk516) was not observed. No differences in background signal intensity between hybridized and untreated samples were obtained.

The application of extraction procedures based on the isolation of bacteria prior to their fixation, or on direct fixation of bacteria in soil and subsequent isolation of the fixed bacteria, resulted in preparations in which the introduced cells could be detected easily. All preparations that contained organic material showed quite intense autofluorescence that disturbed the epifluorescence signals. The intensity of the autofluorescence was more pronounced when pyrophosphate extraction was used. Direct fixation with large amounts of fixation buffer resulted in the lowest autofluorescence.

All soil samples (sandy loam, $8 \%$ organic material) were spiked with about $10^{6}$ cells of $P$. aeruginosa, from which dilutions of $10^{-3}$ and $10^{-4}$ were applied to slides and used for microscope counts after in situ hybridization. The optimal recovery of $10^{3}$ cells $\mu \mathrm{l}^{-1}$ was never achieved. Percentage recoveries of the introduced cells obtained by microscope counts of the larger dilution $\left(10^{-4}\right)$ varied between $10 \%$ and $35 \%$ for the different isolation procedures. Percentage recovery increased with the number of re-extractions and the amount of buffer used, but was independent of the use of pyrophosphate or fixation buffer in the extraction procedure.

These results led to the design of an extraction procedure based on direct fixation of bacteria in a $1 \mathrm{~g}$ soil sample with $5 \mathrm{ml}$ of fixation buffer for 3-16 h. After fixation, heavy soil minerals were separated from the soil suspension by sedimentation under gravity for $2 \mathrm{~min}$ after a short vortex mixing. The remaining mineral pellet was re-extracted with $3 \mathrm{ml}$ of fixation buffer. The combined supernatants were centrifuged at $5000 \mathrm{~g}$ for $10 \mathrm{~min}$, the pellet washed with $1 \mathrm{ml}$ PBS, resuspended in $1 \mathrm{ml} 50 \%$ ethanol/PBS and the solution stored at $-20{ }^{\circ} \mathrm{C}$. This extraction procedure was used in all further experiments.

\section{Soil-dependent detection}

Detection of $P$. aeruginosa cells using the eubacterial probe Eub338 labelled with Tritc was possible in all soils containing different amounts of organic material and of different soil mineral composition (Table 1). The influence of organic material on the detection of specific hybridization signals in soil was more pronounced than the influence of soil minerals. In soils containing large amounts of organic material (peat: over $60 \%$ organic material) the very intense autofluorescence of the organic material made detection difficult but not impossible. Autofluorescence in soils containing smaller amounts of organic material $(1-8 \%)$ did not interfere significantly with the epifluorescence signals. Soil minerals did not disturb detection of the hybridization signals (Fig. 1).

When DAPI was used as the fluorescent dye, strong autofluorescence of soil minerals interfered with the detection of bacterial cells. In contrast to in situ hybridization, detection of bacterial cells was possible only in soils containing low amounts of clay minerals or when large numbers of cells were present $\left[10^{9}\right.$ cells $(\mathrm{g}$ soil) ${ }^{-1}$. Organic substances in these soils did not interfere with DAPI fluorescence.

The percentage recovery determined by microscopy after in situ hybridization or by c.f.u. was soil-dependent, with c.f.u. counts that were always higher than micros-

Table 1. Recovery of $P$. aeruginosa cells added to different soils, determined as no. of c.f.u. and after in situ hybridization

Soils were inoculated with $1.3 \pm 0.2 \times 10^{6}$ cells $\mathrm{g}^{-1}$ of $P$ aeruginosa. Values for recovery are means of three determinations \pm SE.

\begin{tabular}{lccrcr}
\hline \hline & & \multicolumn{3}{c}{ Recovery of $P$. aeruginosa } \\
\cline { 3 - 6 } \multicolumn{1}{c}{$\begin{array}{c}\text { Soil } \\
\text { type }\end{array}$} & $\begin{array}{c}\text { Organic } \\
\text { content* } \\
(\%)\end{array}$ & c.f.u. & $\%$ & $\begin{array}{c}\text { In situ } \\
\text { hybridization }\end{array}$ & $\%$ \\
\hline Sand & 1 & $4.2 \pm 0.7 \times 10^{5}$ & 32 & $4.8 \pm 1.3 \times 10^{5}$ & 37 \\
Sand & 3 & $1.1 \pm 0.0 \times 10^{6}$ & 85 & $2.4 \pm 1.6 \times 10^{5}$ & 18 \\
Sand & 5 & $4.0 \pm 0.3 \times 10^{5}$ & 31 & $0.8 \pm 0.8 \times 10^{5}$ & 6 \\
Peat & 62 & $1.6 \pm 0.1 \times 10^{6}$ & 123 & $3.0 \pm 0.3 \times 10^{5}$ & 23 \\
Sandy loam & 8 & $1.3 \pm 0.2 \times 10^{6}$ & 100 & $5.8 \pm 0.4 \times 10^{5}$ & 45 \\
Sandy clay & 3 & $8.4 \pm 0.4 \times 10^{5}$ & 65 & $1.4 \pm 0.4 \times 10^{5}$ & 9 \\
Clay & 3 & $1.2 \pm 0.6 \times 10^{6}$ & 92 & $8.8 \pm 1.2 \times 10^{5}$ & 68 \\
\hline \hline
\end{tabular}

* Determined by loss on ignition. 

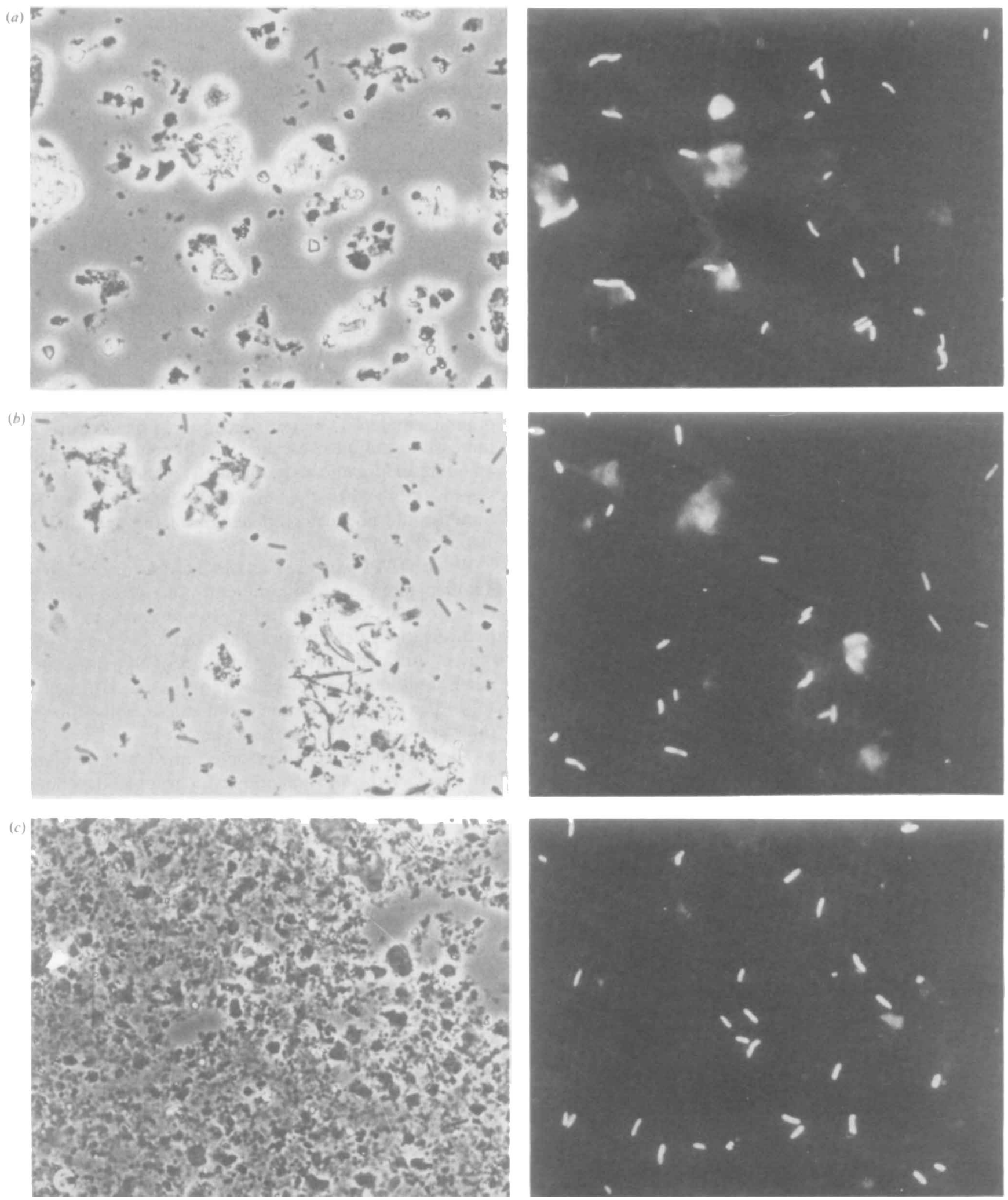

Fig. 1. Detection of $P$. aeruginosa in different soils $-(a)$ sand ( $3 \%$ organic material), $(b)$ peat and $(c)$ clay - after in situ hybridization with the universal probe Eub338 (right-hand panels). The left-hand panels show the corresponding phase-contrast photographs. 

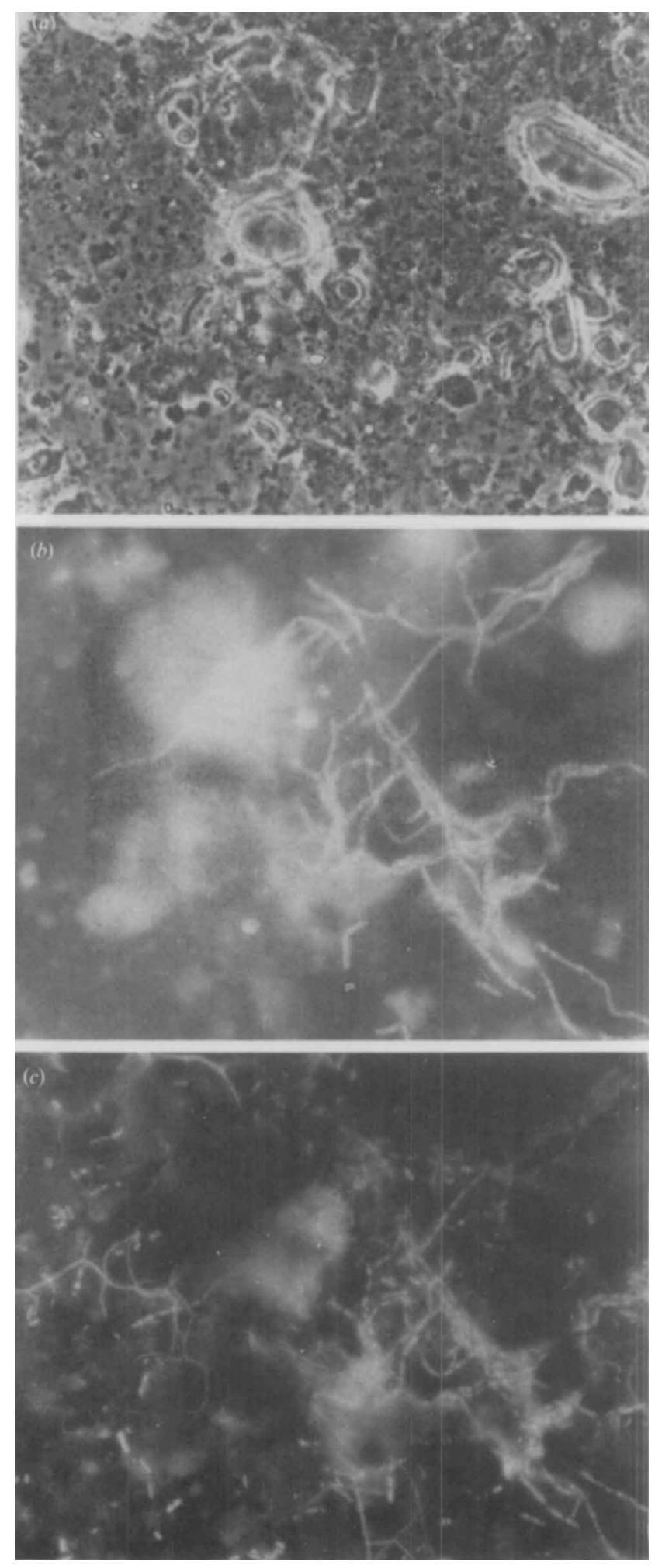

Fig. 2. Specific detection of $P$. cepacia in sandy loam ( $a$, phase contrast) spiked with representatives of different genera of bacteria after in situ hybridization with probe PCE 54 (b). Background organisms were visualized by DAPI staining $(c)$. The following organisms were added in densities of about $10^{8}$ cells of each species per cope counts after in situ hybridization (Table 1). For in situ hybridizations percentage recoveries between $6 \%$ (sand, $5 \%$ organic material) and $68 \%$ (clay) were obtained, whereas c.f.u. counts resulted in percentages between $31 \%$ (sand, $5 \%$ organic material) and $123 \%$ (peat).

\section{Specific detection after in situ hybridization}

$P$. cepacia was specifically detected in in situ hybridizations with probe PCE 54 in the presence of large numbers of background organisms, as determined by DAPI staining (Fig. 2).

\section{Natural populations in soil}

Using the methods described here, in situ hybridization with the universal probe Eub338 with untreated soil samples kept at either $4{ }^{\circ} \mathrm{C}$ or $25^{\circ} \mathrm{C}$ only occasionally resulted in the detection of bacterial cells whereas DAPI treatment of the same samples showed large numbers of very small bacteria (Fig. $3 a, b$ ). After addition of $0.2 \mathrm{ml}$ LB medium and subsequent incubation at $30^{\circ} \mathrm{C}$ for $16 \mathrm{~h}$ many bacteria could, in addition, always be detected after in situ hybridization (Fig. 3c,d).

\section{Detection of inactive cells}

$P$. aeruginosa cells grown on agar plates at different temperatures $\left(20^{\circ} \mathrm{C}\right.$ and $\left.30^{\circ} \mathrm{C}\right)$ showed hybridization signals after in situ hybridization when samples were taken after 1 or $3 \mathrm{~d}$. After incubation for $30 \mathrm{~d}$ only very weak hybridization signals were obtained whereas staining with DAPI indicated the presence of large numbers of cells.

The number of $P$. aeruginosa cells $\left(1.4 \pm 0.2 \times 10^{8}\right)$ introduced into amended gamma-sterilized soil (sandy

gram of soil: Pseudomonas fluorescens (ATCC 11250), P. aeruginosa (P8*), P. putida $\left(\mathrm{P}^{*} 2^{*}\right)$; Bacillus subtilis $\left(\mathrm{B} 28^{*}\right)$, B. megaterium $\left(\mathrm{B} 17^{*}\right)$; Enterobacter agglomerans (E32*), E. cloacae $\left(E 21^{*}\right)$, E. aerogenes (E24*); Azotobacter chroococcum (A40*); Acinetobacter haemolyticus (A191*), A. baumanii (A191*); Klebsiella oxytoca (K10*); Micrococcus luteus (M59*); Serratia marcescens (S60*); Agrobacterium tumefaciens (A182*); Arthrobacter simplex (NCIB 8929), A. globiformis (ATCC 8010); Chromobacterium sp. (ATCC 553); Achromobacter lacticum (NCIB 8208); Flavobacterium aquatile (NCIB 8535); Mycobacterium phlei (ATCC 354); Corynebacterium fascians (C108*); Rhizobium meliloti $\left(\mathrm{R} 17^{*}\right) ; \boldsymbol{R}$. leguminosarum biovar trifolii (TA-1*); Nitrosomonas europaea (ATCC 19718); Escherichia coli (ATCC 11303); Streptomyces scabies (ATCC 13962), S. caesius (ATCC 19828), S. albus (ATCC 3004), S. griseoruber (ATCC 23919), S. violaceoruber (DSM 40783); Rhodococcus chlorophenolicus (DSM 43826); Nocardia convoluta (ATCC 4275), N. vaccinii (ATCC 11092); Micromonospora pupurea (ATCC 15835); and Frankia sp. (AgB1.9* and Ag45/Mut15*).

* Culture Collection, Department of Microbiology, Wageningen, The Netherlands. 


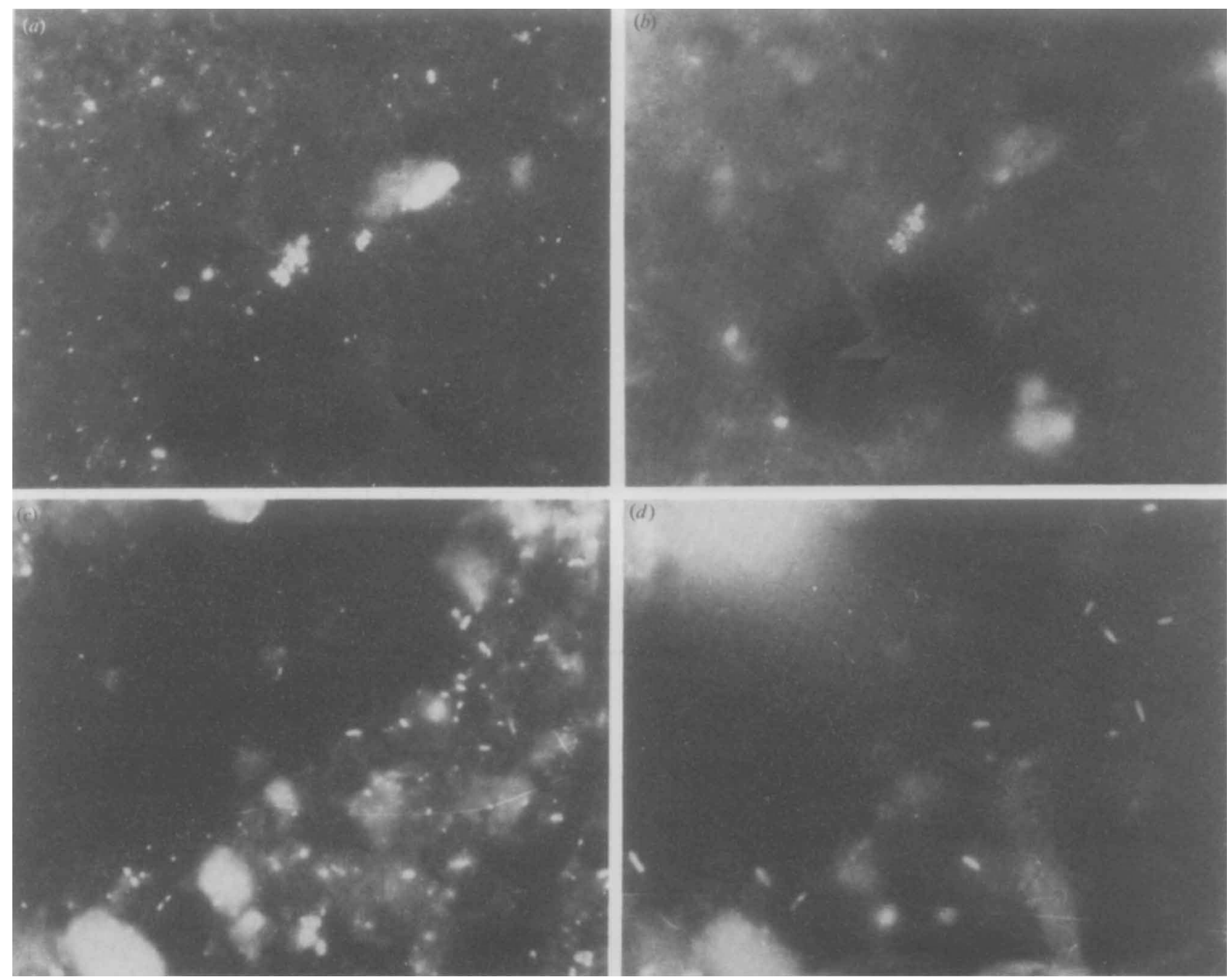

Fig. 3. In situ hybridization of soil samples containing natural bacterial populations with probe Eub338. DAPI staining of untreated soil (a) shows many very small bacteria, while in situ hybridization on the same sample only occasionally revealed a small proportion of the abundant bacteria $(b)$. After addition of nutrients and subsequent incubation the numbers of bacteria detected increased after both DAPI staining $(c)$ and in situ hybridization $(d)$.

loam) and incubated at $20^{\circ} \mathrm{C}$ was stable during a $4 \mathrm{~d}$ incubation period as determined by c.f.u. counts and DAPI staining $\left[1.6-1.1 \times 10^{7}\right.$ cells $\left.(\mathrm{g} \text { soil) })^{-1}\right]$. Detection of bacterial cells after in situ hybridization with probe Eub338 was possible over this period of several days, but the hybridization signals were not as strong as those obtained with cells growing in the exponential phase in liquid medium. The addition of $1 \mathrm{ml}$ of nutrient solution (LB) after $4 \mathrm{~d}$ resulted in an increased bacterial population by day five $\left[10^{9}\right.$ cells $\left.(\mathrm{g} \text { soil })^{-1}\right]$. The larger population could also be observed after in situ hybridization. The hybridization signal was considerably enhanced.

\section{Detection of growing cells}

Growing cells of Streptomyces scabies were easily detected in soil after in situ hybridization (Fig. 4). Hybridization signals with spores were not observed. Pure cultures of cells of $S$. scabies showed much lower permeability for oligonucleotide probes than cells grown in soil. Hybridization signals with pure cultures were obtained only when cells were pretreated with lysozyme (0.1\% lysozyme for $15 \mathrm{~min}$ at room temperature). This pretreatment was not necessary when $S$. scabies was growing in soil. 

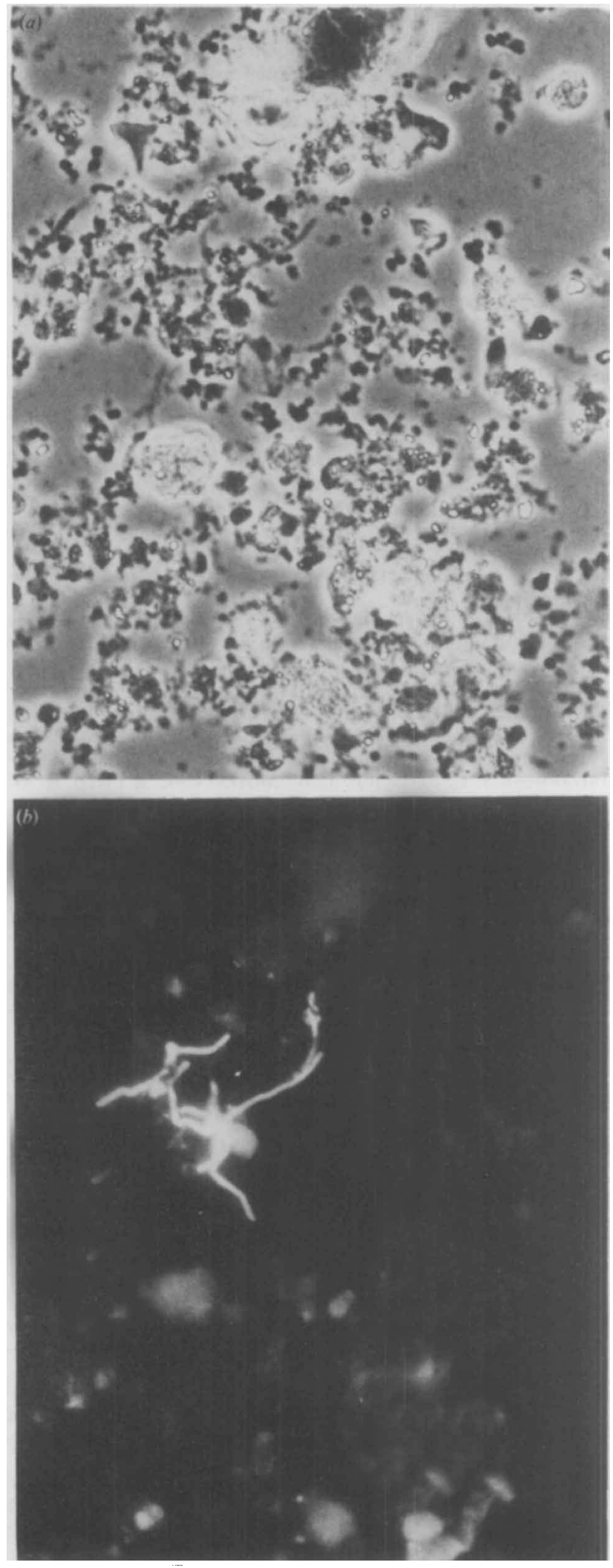

Fig. 4. Hyphae of $S$. scabies growing in sterile amended soil (a, phasecontrast) visualized after in situ hybridization with probe Eub338 (b).

\section{Discussion}

In situ hybridization with rRNA-targeted oligonucleotides labelled with fluorescent dyes was applicable for detection of bacteria in soil. Hybridization results were influenced by several factors, such as the extraction procedure, the environmental conditions and the metabolic state of the target organisms. Non-specific binding of the probe to soil particles was not observed. Counterstaining and blocking techniques that are used in the application of fluorescent antibodies were therefore not required (Bohlool \& Schmidt, 1968).

The intensive autofluorescence of soil organic compounds, especially in soils such as peat containing large amounts of organic material, could interfere with the detection of low numbers of bacteria. Smaller amounts of organic material (up to $8 \%$ in the sandy loam) did not significantly influence the hybridization signals. The amount of organic material in the sample depended on the extraction procedure, i.e. whether cells were extracted from soil prior to their fixation or whether the cells were directly fixed in soil and then extracted. Pyrophosphate extraction of cells resulted in higher contamination with organic material than direct fixation and subsequent extraction with fixation buffer. The latter procedure kept organic material in larger particles. Autofluorescence of these particles can make the fluorescent hybridization signal of attached bacteria undetectable. In our studies with introduced bacteria autofluorescence did not result in lower cell counts; however, detection of populations growing in soil is expected to be affected much more, since their lower physiological activity will result in a lower specific hybridization signal.

Direct fixation of bacteria in soil also minimized losses of bacteria attached to soil minerals (clay, sandy clay) during a first extraction procedure. To circumvent such recovery problems only large soil particles were removed from the preparation. Optimal recovery of bacterial cells grown in soil, however, needed more rigorous procedures to break up soil clumps (Fry, 1990).

The application of a thin soil smear to slides for in situ hybridization gives a theoretical detection limit of $10^{2}-10^{3}$ cells $\mathrm{g}^{-1}$, depending on the soil and the amount of liquid needed to obtain a soil suspension. Soils containing mainly sand can be suspended in lower amounts of liquid than soils containing large amounts of clay minerals. In our experiments percentage recoveries between $6 \%$ and $68 \%$ were obtained depending on the soil. However, compared to c.f.u. counts, the recoveries determined by in situ hybridization always show lower figures. Additional studies are necessary to achieve higher recoveries.

The development of the in situ hybridization procedure 
in soils was performed with metabolically active cells. In nature, bacterial cells are often metabolically inactive and embedded in a matrix of polysaccharides (Roszak \& Colwell, 1987). Because the amount of rRNA is correlated with the activity of cells (DeLong et al., 1989a) it is not surprising that in situ hybridization with rRNAtargeted probes on natural populations of bacteria grown in soil did not result in significant hybridization signals. The application of fluorescent rRNA probing is currently limited to physiologically active bacteria, i.e. those found in environments rich in nutrients such as activated sludge in which many organisms exist that cannot be easily obtained in pure culture, e.g. syntrophic organisms or bacterial endosymbionts (Amann et al., 1991).

Apart from the activity of the target cells, reliable detection is also dependent on probe specificity. Probe specificity of oligonucleotide probes can generally be freely adjusted (Amann et al., 1990a). However, specificity tests done on a limited number of laboratory strains do not really exclude non-specific binding to cells and soil particles, cross-hybridization to bacteria other than the target organism when applied in natural bacterial populations (Stahl et al., 1988), or lower specificity for additional target organisms, e.g. different strains of one species (Hahn et al., 1990a).

The approach of applying rRNA-targeted oligonucleotides in in situ hybridization in soil offers not only an alternative to serological approaches in the analysis of natural bacterial communities. The combination of DNA/rRNA extraction procedures from soil, the selective amplification of rRNA sequences and the subsequent sequence analysis of cloned amplification products show a high potential for obtaining specific probes against uncultured and unculturable micro-organisms (Giovannoni et al., 1990; Ward et al., 1990a, b; Amann et al., 1991). These probes could be used to detect and quantify specifically these organisms after in situ hybridization. However, future developments must focus on signal amplification, either by the use of multiple probes or by other labelling strategies in order to expand the applicability of these probes to cells with low rRNA content.

This work was supported by grants from the Netherlands Integrated Soil Research Programme (project no. 8965) and the Deutsche Forschungsgemeinschaft (DFG).

\section{References}

AmanN, R. I., Krumholz, L. \& Stahl, D. A. (1990a). Fluorescentoligonucleotide probing of whole cells for determinative, phylogenetic, and environmental studies in microbiology. Journal of Bacteriology 172, 762-770.

Amann, R. I., Binder, B. J., Olson, R. J., Chisholm, S. W., DeVereux, R. \& Stahl, D. A. (1990 b). Combination of 16S rRNAtargeted oligonucleotide probes with flow cytometry for analyzing mixed microbial populations. Applied and Environmental Microbiology 56, 1919-1925.

Amann, R. I., Springer, N., Ludwig, W., Görtz, H.-D. \& SCHLEIFER, K.-H. (1991). Identification in situ and phylogeny of uncultured bacterial endosymbionts. Nature, London 351, 161-164.

Bej, A. K., DiCesare, J. L., HafF, L. \& ATlas, R. M. (1991). Detection of Escherichia coli and Shigella spp. in water by using the polymerase chain reaction and gene probes for uid. Applied and Environmental Microbiology 57, 1013-1017.

BohloOL, B. B. \& SchmidT, E. L. (1968). Nonspecific staining: its control in immunofluorescence examination of soil. Science 162, 1012-1014.

BoHLOOL, B. B. \& SCHMIDT, E. L. (1980). The immunofluorescence approach in microbial ecology. Advances in Microbial Ecology 4, 203241.

BROCK, T. D. (1987). The study of microorganisms in situ: progress and problems. Symposia of the Society for General Microbiology 41, 1-17.

DeLong, E. F., Wickham, G. S. \& PaCe, N. M. (1989a). Phylogenetic stains: ribosomal RNA-based probes for the identification of single cells. Science 243, 1360-1363.

DeLong, E. F., Schmidt, T. M. \& Pace, N. R. (1989b). Analysis of single cells and oligotrophic picoplankton populations using $16 \mathrm{~S}$ rRNA sequences. In Recent Advances in Microbial Ecology, pp. 697701. Edited by T. Hattori, Y. Ishida, Y. Maruyama, R. Morita \& A. Uchida. Tokyo: Japan Scientific Societies Press.

FRY, J. C. (1990). Direct methods and biomass estimation. Methods in Microbiology 22, 41-86.

Fuhrman, J. A. \& Lee, S. H. (1989). Natural microbial species variations studies at the DNA level. In Recent Advances in Microbial Ecology, pp. 687-691. Edited by T. Hattori, Y. Ishida, Y. Maruyama, R. Morita \& A. Uchida. Tokyo: Japan Scientific Societies Press.

Giovannoni, S. J., Delong, E. F., Olsen, G. J. \& Pace, N. R. (1988). Phylogenetic group-specific oligonucleotide probes for identification of single microbial cells. Journal of Bacteriology 170, 720-726.

Giovannoni, S. J., Britschgi, T. B., Moyer, C. L. \& Field, K. G. (1990). Genetic diversity in Sargasso Sea bacterioplankton. Nature, London 345, 60-63.

Grant, M. A. \& Holt, J. G. (1977). Medium for the selective isolation of members of the genus Pseudomonas from natural habitats. Applied and Environmental Microbiology 33, 1222-1224.

GraY, T. R. G. (1990). Methods for studying the microbial ecology of soil. Methods in Microbiology 22, 309-342.

Hahn, D., Starkenburg, M. J. C. \& Akkermans, A. D. L. (1990a) Oligonucleotide probes that hybridize with rRNA as a tool to study Frankia strains in root nodules. Applied and Environmental Microbiology 56, 1342-1346.

Hahn, D., Kester, R., Starkenburg, M. J. C. \& Akrermans, A. D. L. $(1990 b)$. Extraction of ribosomal RNA from soil for detection of Frankia with oligonucleotide probes. Archives of Microbiology 154, 329-335.

Herron, P. R. \& Wellington, E. M. H. (1990). New method for extraction of streptomycete spores from soil and application to the study of lysogeny in sterile amended and nonsterile soil. Applied and Environmental Microbiology 56, 1406-1412.

HiLl, I. R. \& GRAY, T. R. G. (1967). Application of the fluorescentantibody technique to an ecological study of bacteria in soil. Journal of Bacteriology 93, 1888-1896.

Höpfl, P., LudWiG, W., SChleifer, K.-H. \& LARSEN, N. (1989). The 23S ribosomal RNA higher-order structure of Pseudomonas cepacia and other procaryotes. European Journal of Biochemistry 185, 355364.

Holben, W. E., Jansson, J. K., Chelm, B. K. \& Tiedje, J. M. (1988). DNA probe method for the detection of specific microorganisms in the soil bacterial community. Applied and Environmental Microbiology 54, 703-711.

Hopwood, D. A., BibB, M. J., Chater, K. F., Kieser, T., Bruton, C. J., Kieser, H. M., Lydiate, D. J., SMTth, C. P., WARD, J. M. \& SCHREMPF, H. (1985). Genetic Manipulation of Streptomyces. Norwich: John Innes Foundation.

Maniatis, T., FriTsCh, E. F. \& SAMBrook, J. (1982). Molecular Cloning. A Laboratory Manual. Cold Spring Harbor, NY: Cold Spring Harbor Laboratory. 
Porter, K. G. \& FeIG, Y. S. (1980). The use of DAPI for identifying and counting aquatic microflora. Limnology and Oceanography 25, 943-948.

Postma, J., van Elsas, J. D., Govaert, J. M. \& van Veen, J. A. (1988). The dynamics of Rhizobium leguminosarum biovar trifolii introduced into soil as determined by immunofluorescence and selective plating techniques. FEMS Microbiology Ecology 53, 251260.

RoszaK, D. B. \& Colwell, R. R. (1987). Survival strategies of bacteria in the natural environment. Microbiological Reviews 51, 365-379.

Sayler, G. S., Fleming, J., Applegate, B., Werner, C. \& NikbaKht, K. (1989). Microbial community analysis using environmental nucleic acid extracts. In Recent Advances in Microbial Ecology, pp. 658-662. Edited by T. Hattori, Y. Ishida, Y. Maruyama, R. Morita \& A. Uchida. Tokyo: Japan Scientific Societies Press.

Stahl, D. A., Flesher, B., Mansfield, H. R. \& Montgomery, L. (1988). Use of phylogenetically based hybridization probes for studies of ruminal microbial ecology. Applied and Environmental Microbiology 54, 1079-1084.

Stahl, D. A., DevereuX, R., Amann, R. I., Flesher, B., Lin, C. \& Stromley, J. (1989). Ribosomal RNA based studies of natural microbial diversity and ecology. In Recent Advances in Microbial Ecology, pp. 669-673. Edited by T. Hattori, Y. Ishida, Y. Maruyama, R. Morita \& A. Uchida. Tokyo: Japan Scientific Societies Press. Steffan, R. J. \& ATLAS, R. M. (1988). DNA amplification to enhance detection of genetically engineered bacteria in environmental samples. Applied and Environmental Microbiology 54, 2185-2191.

THOMPSON, I. P., COOK, K. A., LeTHBRIDGe, G. \& BURNS, R. G. (1990). Survival of two ecologically distinct bacteria (Flavobacterium and Arthrobacter) in unplanted and rhizosphere soil: laboratory studies. Soil Biology and Biochemistry 22, 1029-1037.

Torsvik, V., Goksoeyr, J. \& DAAE, F. L. (1990). High diversity in DNA of soil bacteria. Applied and Environmental Microbiology 56, 782-787.

WARD, D. M. (1989). Molecular probes for analysis of microbial communities. In Structure and Function of Biofilms, pp. 145-163. Edited by W. G. Characklis \& P. A. Wilderer. Chichester: John Wiley.

Ward, D. M., Weller, R. \& Bateson, M. M. (1990a). 16S rRNA sequences reveal uncultured inhabitants of a well-studied thermal community. FEMS Microbiology Reviews 75, 105-116.

WARD, D. M., Weller, R. \& BATESON, M. M. $(1990 b)$. 16S rRNA sequences reveal numerous uncultured microorganisms in a natural community. Nature, London 345, 63-65.

WELLER, R. \& WARD, D. M. (1989). Selective recovery of 16 S rRNA sequences from natural microbial communities in the form of cDNA. Applied and Environmental Microbiology 55, 1818-1822.

Wellington, E. M. H., Al-JAWAdi, M. \& Bandoni, R. (1987). Selective isolation of Streptomyces species-groups from soil. Developments in Industrial Microbiology 28, 99-104. 